\title{
Informal economy as a cause for understating actual rates of entrepreneurship among blacks in the U.S. and in Africa
}

\author{
Micah E. S. Crump \\ Department of Public Administration \\ Medgar Evers College, CUNY, U.S.A \\ Nicholas J. Hill \\ Department of Economics \\ Jackson State University, U.S.A \\ Bradley W. Hardin \\ Department of Accounting \\ Jackson State University, U.S.A
}

\section{Key words}

Informal economy, Africa, black entrepreneurship, Nigeria

\begin{abstract}
The study presents considerations for African countries that build off of Crump, Hill, and Taylor (2017). In that study, Crump et al. (2017) argue and present empirical evidence to support the notion that rates of black entrepreneurship (measured by black business ownership) in the U.S. currently presented in entrepreneurship literature are misleading and understated. Once formal and informal economy are considered together, the authors propose that entrepreneurship rates of blacks drastically increase, and likely surpass many other groups. This exploratory study similarly argues and presents evidence that actual rates of business ownership and entrepreneurship derived from formal economy activities in Africa likewise understate the actual rates of entrepreneurship and business ownership there. This study also shows that there are many more advantages to operating in the formal economy than there are to be operating in the informal economy. A tool is provided that can aid entrepreneurship educators to highlight some hidden advantages and disadvantages to people choosing to operate in either economy.
\end{abstract}

Corresponding author: Micah E. S. Crump

Email address for corresponding author: mcrump@mec.cuny.edu

First submission received: $30^{\text {th }}$ April 2018

Revised submission received: $20^{\text {th }}$ November 2018

Accepted: 30th November 2018

\section{Introduction}

\subsection{Understated Black Entrepreneurship Rates}

Crump, Hill, and Taylor (2017) argue that in the United States the rate of black entrepreneurship, measured by black business ownership, currently presented in the entrepreneurship literature is misleading and understated. The extant findings in the entrepreneurship literature indicate that blacks in the U.S. have the lowest rates of established business ownership at just four percent (Fairlie and Meyer, 1996, 2000; Fairlie and Robb, 2007) while also having the highest rates of entrepreneurial propensity, interest, and nascent entrepreneurship (Köllinger and Minniti, 2006; Walstad and Kourilsky, 1998). This rate is one third that of white established business ownership which is 12 percent, and this one-to-three 
percentage ratio has remained constant for more than the past 100 years (Bates, 1996; Fairlie, 1999; Fairlie and Meyer, 1996, 2000).

The literature also shows that blacks in the U.S. are unique relative to most other major racial and ethnic groups studied in the literature (Bradford, 2003; Butler, 1991; Hout and Rosen, 2000; Singh, Crump, and $\mathrm{Zu}, 2009$ ). They are likely to engage in entrepreneurial activities differently than others (Crump 2013; Crump et al., 2017). Most of the findings on them relate to entrepreneurs who operate registered businesses in the formal economy. This led Crump et al. (2017) to question if the exceptionally low rates of black business ownership in the U.S. relative to non-black population groups there result primarily from a measurement issue.

From the literature, the researchers hypothesized that certain forces act greater on blacks relative to non-blacks leading blacks to operate businesses in the informal economy at a significantly higher rate (see Crump 2013 for a more detailed explanation). Given the challenges of measuring informal economy activity (Macias and Cazzavillan, 2010; Schneider, 2005a, 2005b) among racial and ethnic groups, Crump et al. (2017) analyzed indirect measures and found that as the percentage of black population density increases in areas in the United States, those areas are more likely to contain a higher proportion of entrepreneurs operating in the informal economy. The researchers further established an Informal Economy Index (IEI) that can be used to measure the level of a city's informal economy activity based on its percentage of black population.

Crump et al.'s (2017) IEI supports their proposition that the well-established findings surrounding the underrepresentation of blacks in entrepreneurship compared to other groups diminish when the informal economy is factored into consideration. Once formal and informal economy are considered together, the authors propose that the sum of entrepreneurship rates of blacks drastically increase and likely surpass many other groups who operate in both economies. Similarly, actual rates of business ownership and entrepreneurship derived from formal economy activities in Africa likewise may understate the actual rates of entrepreneurship and business ownership there.

The implications of understated entrepreneurship rates among a population group may carry severe negative consequences. Such consequences may be experienced by the group, or by other affected outside groups and the broader community, society, and economy. Examples include prospective suppliers, partners, and investors who forego opportunities because the opportunities remain hidden. Additional groups include policy-makers, government officials, and grant funding institutions that divert resources elsewhere because of distorted perspectives on the actual entrepreneurial opportunities that exist among these hidden entrepreneurs. If systemic forces act more strongly on any particular ethnic, racial, or national group to understate that group's entrepreneurship rates, then research efforts to reveal these hidden forces should prove a worthwhile undertaking.

\subsection{Aims of this Research}

We believe the extent to which geographic areas marked by high black population density correspond to increasing levels of informal economy activity compared to geographic areas of lower black population density is an interesting empirical question. Countries like Brazil and Guyana in South America, and many countries throughout the Caribbean and Africa have high concentrations of black population density and are therefore ideal for such investigation. Thus, one aim of this exploratory study is to contribute to a foundation that argues for such investigation beginning in countries in Africa. We begin this endeavor by investigating whether any adverse impacts stemming from an underestimation of black entrepreneurs in the U.S. likewise relate to black entrepreneurs and business owners in Africa whose entrepreneurship rates may also be largely understated. A second aim of this study is to explore any importance to policymakers and educators in both Africa and in the U.S. teaching entrepreneurs and business owners about 
differences and trade-offs of operating in either the formal or informal economy. Finally, we hope that this study contributes to a growing body of work that aims to increase any suppressed rates of entrepreneurship among blacks both in the U.S. and in African nations.

\section{Literature Review}

\subsection{What is the Informal Economy?}

The informal economy is difficult to clearly define (Chen, 2012; Macias and Cazzavillan, 2010; Schneider, 2005a). Yet, it is an economy that is active in all countries around the world (Schneider, 2002 and 2005b), and is increasing (Murkherjee, 2016; Schneider, 2005b). Murkherjee (2016) presents a nice typology of works that illuminate this economy. In many developing nations, this sector accounts for more than half of all economic output (Godfrey, 2011). Chen (2012) shows how four different schools of thought (Dualist, Structuralists, Legalists, and Volunteerists schools) distinctively view and define this economic sector differently than each other. The International Conference of Labour Statisticians (ICLS) defines the informal sector as employment and production that takes place in unincorporated small and/or unregistered enterprises and includes all types of informal employment both inside and outside informal enterprises (Chen, 2012). This informal economic sector is comprised of several sub-dimensions that are easier to define. Some researchers partition the informal economy based on illegal versus legal activities, overlaid against illegitimate versus legitimate activities (e.g., Crump et al., 2017; Schneider, 2005a; Williams and Shahid, 2016). For our current discussion, we focus on the dimension that consists of business trade activities that would otherwise be lawful if the activities were taxed, licensed, regulated, and recorded.

\subsection{What Causes People to Choose the Informal Economy Option?}

Many forces lead people to operate in the informal economy, such as high unemployment, regulation, corruption, taxation, administration, and low salary levels and quality of public goods such as infrastructure (DeSoto, 1989; Dreher and Schneider, 2010; Johnson et al., 1998; Kaufmann, 1997; Khavul, Bruton, and Wood, 2009; Maloney, 2004; Schneider, 2005a; Shleifer, 1997; Shleifer and Vishny, 1993; Shleifer and Vishny, 1994; Shleifer and Vishny, 1998; Schuck and Litan, 1987; Williams and Round 2008). In nations where, low contract enforcement and inefficient institutional environments abound, potential entrepreneurs are pushed into the informal economy (Mukherjee 2016). People with high income levels choose the informal economy option out of having the discretion to run a business or not to run a business as a secondary source of income (Williams, 2008; Williams and Round, 2010). High income people also choose this option to increase wealth, business acumen, and access to resources (Webb et al., 2009), to escape corruption and bribes (Williams and Round, 2008), and to exploit opportunities from pre-existing formal employment (Williams, 2008; Williams, 2010; Williams and Nadin, 2010). People with middle income levels choose to operate in the informal economy also out of choice (Williams and Round, 2010, 2007), for hobby/personal interest reasons (Williams and Round, 2007), and to reduce risks with formal employment (Williams and Round, 2007).

People with low income have additional reasons to choose the informal economy. These include (1) for survivalists purposes, out of necessity, and as a main source of income (Edgcomb and Thetford, 2004; Williams, 2008; Williams, 2010; Williams and Nadin, 2010; Williams and Round, 2010); (2) because they are undercapitalized, and because they perceive themselves as targets of discriminatory practices in the formal labor market (Webb et al., 2009); (3) to reduce risks associated with formal employment (Williams and Round, 2007) such as demotion or dismissal; (4) to gain dignity and autonomy that they believe cannot easily be attained in formal employment (Maloney, 2004); (5) to favorably transform their work identity (Cross, 2000); and (6) because of hobbies, or personal interest (Edgcomb and Thetford, 2004; 
Williams and Nadin, 2010). Some entrepreneurs make the choice to operate in either the formal or informal economy, only (Schneider, 2005a). Others choose to operate in both simultaneously by formalizing their business activities while also keeping some portion of their trade activities hidden. The criteria that guide this choice relates to perceived positive and negative tradeoffs that accompany both choices (Guillermo, 2008). Some of these trade-offs are advantages, and others are disadvantages. A third group of people unwittingly find themselves simply trading in a non-formal way in the informal economy, without really giving any thought to the existence of any official rules and regulations governing their business trade. This highlights that many who operate in the informal economy never make an explicitly conscious choice to do so.

\subsection{Trade-offs: Formal Versus Informal Economy}

In a nation's formal economy, primarily all businesses are registered, and their income taxed. Most new and existing businesses are required to secure some sort of industry-specific license to ensure safety and harm remain in balance. Businesses must also obtain some type of general license(s) that grants permission to sell to the public and hire employees. These businesses, then, are registered, taxed, licensed, and regulated. Incentives for accepting these regulations are many. First, informal sector businesses cannot fully take advantage of market-supporting institutions and their access to capital is drastically limited (De Soto, 1989; Kaufman and Kaliberda, 1996; Johnson, McMillan, and Woodruff, 1999). By becoming registered on public registries, these businesses enjoy more visibility to a broader market of potential customers, suppliers, investors, and other types of strategic partners. In contrast, if a business does not register, it typically remains visible only to smaller localized markets of customers at arm's length of the business owner.

By becoming a legally identifiable business, the owner can convert the business into a separate legal entity such as a corporation or limited liable company. Prior to such a change, that business can be thought of as only being a verb. That is, the business is not a thing or noun. Instead, the business is simply an action (i.e., a verb) that an owner does. When a business remains a verb, it and the owner are one in the same. Thus, no portion of the business can be traded as equity ownership in exchange for needed capital because a business owner cannot sell a portion of his actions. Additionally, the owner is personally and fully liable for all of the business' actions and liabilities. Also, when an entrepreneur instead registers his/her new or existing business as a legal entity, the business becomes a noun, and any portion of that business (the legal entity that is separate from the owner) can be sold or traded in exchange for equity. Formalizing one's business also enhances its legitimacy and brand to most stakeholders including customers, lenders, investors, and key recruits. Additionally, formalizing a business secures the right to use court services to settle disputes, and police and emergency fire services without reparation. Chen (2012) summarizes these benefits as providing: access to finance and market information; access to public infrastructure and services; enforceable commercial contracts; limited liability; clear bankruptcy and default rules; access to government subsidies and incentives including procurement bids and export promotion packages; membership in formal business associations; and access to a formal system of social security.

We ask: Do trade-offs differ among entrepreneurs who operate in the informal economy in the U.S. relative to those who operate in the informal economy in Africa? Africa is an enormous, multifaceted, and highly diverse geographic area that consists of many countries. These countries vary drastically from each other in many ways including climate, religion, culture, political system, language, ethnicity, infrastructure development, and legal/regulatory environment. Research efforts to identify specific barriers and opportunities that relate unilaterally to the region are scant. Thus, literature available on African countries 
typically focuses on some smaller subset of countries. Nonetheless, some generalizations have been identified in the literature.

\subsection{Entrepreneurship Education in Africa}

Africa is a very young population with nearly 60 percent of its people being younger than 25 years. Only one in four children receive a secondary education, and less than five percent of these receive any type of vocational training (Kshetri, 2011). Entrepreneurship education could provide a helpful addition. DeJaeghere and Baxter (2014) point out, however, that much of the entrepreneurship education currently in Africa consists of necessity-driven training aimed at creating micro-enterprises and livelihood options aimed at getting out of poverty. In contrast, opportunity entrepreneurship education there would more so be aimed toward broader business and economic development. But such improvements rely on national and local governments cultivating the necessary conditions for youth to succeed in entrepreneurship. Otherwise, necessity entrepreneurs will fail as they transition into competitive and struggling marketplaces (DeJaeghere and Baxter, 2014; Libombo and Dinis, 2015).

\subsection{Perceptions of Entrepreneurship in Africa}

In general, people in West Africa value being an entrepreneur (Amine and Staub, 2009; Kiggundu, 2002; Rheault and Tortora, 2008). Yet, negative perceptions also exist. Many in Africa including some governments believe that being self-employed in a small enterprise equates to being unemployed (Amine and Staub, 2009). Given that West African countries are primarily collectivist societies (Hofstede, 1983) others believe that entrepreneurial status creates a duty that an entrepreneur share his/her income with extended family members and others when needs arise. This belief and practice are seen as negatively disadvantaging one's business performance, and for many, it serves as a deterrent to business ownership (Kiggundu, 2002).

Some West African entrepreneurs even relocate their businesses away from their hometown because of fear of the business becoming encumbered with family members (Robinson et al., 2009). Further, especially in rural areas, there is a strong incidence of belief in witchcraft where sorcerers provide blessings, curses, and protection. Amine and Staub (2009) explain the widespread belief that entrepreneurs who are perceived as shirking their expectations to support extended family members through hard times may risk becoming the object of a curse. This fear likewise discourages some potential entrepreneurs from actually venturing into entrepreneurship.

Loyalty to such strong ties is also causally linked to fewer innovations coming from African businesses than from those in other more developed countries (Robinson et al., 2009). In the case of Ghana, there is a tendency for entrepreneurs to employ family members rather than more qualified applicants which likely result in a workforce that is less creative and lacking independent thinking (Robinson et al., 2009). Additionally, Robinson et al. (2009) show that people in Ghana view and treat older people as wiser and more knowledgeable. These tendencies serve to counter creativity and innovation by younger minds in favor of the more conventional wisdom of older people.

\subsection{Women and Entrepreneurship in Africa}

While there is a general sense among Africans that entrepreneurship has value and is regarded favorably, there is also a strong negative attitude toward women entrepreneurs at the community level (Amine and Staub, 2009; Rheault and Tortora, 2008). Amine and Staub (2009) provide a detailed explanation on many systemic barriers that women in Africa face in trying to become entrepreneurs. So while many exceptions exist where African women are making huge strides and becoming successful global entrepreneurs, the bulk of women-owned businesses in Africa are informal economy firms, formed out of necessity, and small-scaled enterprises (Amine and Staub, 2009; DeJaeghere and Baxter, 2014). 


\subsection{Political Environment in Africa}

Throughout much of Africa, government and the private sector share the factors of production. Therefore, in these mixed economies the governments are the largest employers since they have nationalized many of the nation's firms. Governments also control large portions of countries' national resources (Kshetri, 2011; Mvunganyi, 2010). African entrepreneurs in Africa compete with many ethnic migrants from outside regions who have moved to Africa in search of entrepreneurial opportunities. These non-African immigrants typically possess more formal education and better business networks and are therefore able to establish competitive advantages over indigenous black entrepreneurs there. As a result, these non-African immigrant entrepreneurs stake out strongholds in certain markets and create restricted access to those markets by prospective local African entrepreneurs (Amine and Staub, 2009).

Kshetri (2011) explains that these types of activities in Africa from foreign firms come at the expense of local entrepreneurs. Citing an example from illegal-fishing.info (2007) where thousands of fishermen on Africa's coast have lost jobs, Kshetri (2011) argues that the political process in a given country has a built-in bias that favors organized groups and industries compared to those that are unorganized (Mitra, 1999, as cited in Kshetri, 2011). Because most African countries do not have large and organized local commercial fishing industries to pressure their governments, outside organized groups and industries out lobby the local African groups to enacts laws and policies in the outside groups' favor, and to the local citizens' demise (Kshetri, 2011).

\subsection{Regulatory Environment in Africa}

Africa creates fewer new firms than any other region in the world (Klapper and Love, 2010; Munemo, 2012). Regulation is largely to blame (Kus, 2010). In Sierra Leone, for example, formal firms often pay as much as three times their profit in taxes. In Angola, the procedures to formalize a business often take 1,000 days or more (The Economist, 2006). These examples illustrate why many entrepreneurs throughout the continent strategically remain small and informal (Fadahunsi and Rosa, 2002). In response, many African countries are attempting substantial business entry reforms (Atchoarena and Delluc, 2001; Kent and Mushi, 1995; Okpara and Wynn, 2007). Some governments have even given small business owners the option to pay for a license that allows them to do business, while also remaining informal when it comes to paying taxes (Amine, and Staub, 2009). Most African countries also lack strong protection for property rights (Mbaku, 2007) in spite of available knowledge that developing economies cannot reach their economic potential without the ability to ensure impartial enforcement of contracts (Olson, 1996; Sievers, 2001).

\subsection{Entrepreneurship and Corruption in Africa}

Countries with burdensome regulation of entry have higher levels of corruption (Djankov et al., 2002). In turn, corruption is associated with increased levels of informal activity (Friedman et al 2000; Bhattacharya and Ghose, 1998), and causes a tremendous and detrimental impact on economic growth (Svensson, 2005). In Africa, corruption is identified as a major impediment to entrepreneurship (Goedhuys et. al., 2016). World Bank enterprise survey data (2015) shows some African countries are ranked 2nd in all categories behind Asia for corruption activity and its impact on factors that influence entrepreneurial growth.

\subsection{Digital Divide in Africa}

Accessing technology is a critical determinant to entrepreneurial success. Murthy et al. (2015) show that recent internet access by countries in Africa is enormously low, and that the observed digital divide is continually widening. In spite of this divide, however, explosive internet connectivity is occurring in some countries on the continent. Nigeria is leading the charge in millions of new internet 
users. Kenya, Madagascar, Malawi, Mali, Sudan, and Tanzania are some of the other top ten countries in millions of new internet users on the continent (Musarurwa and Jazri, 2014). Sadly though, this sudden increase across the region is also a major cause of an increase in cybercrime there (Krizinger and Solms, 2012). This phenomenon has prompted Oladipo (2015) to explain that cyber-crime is Africa's next big threat.

\subsection{Informal Economy in Africa}

Schneider (2005) calculated 41.3 percent as the portion of Africa's economic activity that occurs in the informal economy. Seven years later, the International Labor Organization (2012) reported that 72\% of all non-agricultural employment in sub-Saharan Africa is informal, and that $70 \%$ of this informal employment can be categorized as self-employment. Thus, roughly half of all sub-Saharan African employment exists in the informal economy. Although motivations for becoming an entrepreneur is increasingly becoming opportunity-based instead of necessity-based (Kshetri, 2011), a primary reason such a large portion of Africans trade in the informal economy is out of necessity (Schneider, 2005). For many citizens, the informal sector is the only place they can work in order to achieve a minimum standard of living (Schneider, 2005). But as we have presented earlier, excessive regulation is also a primary reason why people trade in the informal economy in Africa. Zimbabwe, Tanzania, and Nigeria contain the largest portion of informal economy activity accounting for 63.2, 60.2 and 59.4 percent respectively of official GDP.

Nigeria contains the largest population size of 182.2 million people out of all African countries, with Tanzania containing 53.5 million residents, and Zimbabwe having 15.6 million (Worldbank, 2015). One study found that 69 percent of potential entrepreneurs in Nigeria would not formally register their businesses, while only 19 percent would (Kshetri, 2011; Rheault and Tortora, 2008). With a population of 55.0 million, South Africa is considered the largest center of entrepreneurial activities in Africa (Ford, 2009). Along with Mauritius (1.3 million population), Namibia (2.5 million population) and Botswana (2.3 million population), these four countries rank among the world's top 50 countries in entrepreneurial climate and ease of doing business (Kshetri, 2011; The Economist, 2006a).

\section{Findings and Discussion}

There are several findings we wish to highlight. First, the findings on corruption in Africa lead us to question whether corruption as language and practice leads to a broadly accepted notion that corruption exists much more so in the region than it actually does. Many practices that are referred to as "corruption" in informal settings are actually similar to actions that are considered license-, permits-, expedite fees-, and other similar collections in formal settings. If any of these practices are otherwise identical with the exception being the level of formalization among a particular governing institution or person, then this phenomenon currently conceptualized as corruption should be shed in a different light.

Consider any country in a least developed nation that has government bodies spread throughout the country. The degree of formalization and centralization of many of its government practices and procedures may be far less formal than those same practices and procedures in highly developed nations. Thus, the only difference between some of that which is considered corruption in Africa, and which is broadly accepted as legal and legitimate in developed countries, may simply be a matter of language. If some activities in Africa are no different than a city comptroller or cashier in a small city in the U.S. performing the same action, except in a formal manner, then the implications to the broadly accepted notion of Africa being highly corrupt could be substantial. 
Second, the findings and statistics presented above on the informal economy in Africa reveal an interesting story when population sizes are factored into consideration. The combined populations in 2015 of the previously presented top four countries in Africa based on entrepreneurial activities, Mauritius, Namibia, Botswana, and South Africa amount to one-third (33.5 percent) of Nigeria's total population (Worldbank, 2015). If, as presented earlier, 69 percent of potential entrepreneurs in Nigeria's population go on to operate in the informal economy, then this number of informal economy entrepreneurs likely far exceeds the total number of entrepreneurs in all four of the top African entrepreneurial countries. It is also quite conceivable that the number of informal economy entrepreneurs in Nigeria may also exceed the total combined population in all four countries as well (See Table 1).

\begin{tabular}{|l|l|l|}
\hline Top Informal Economy Countries in Africa & \multicolumn{1}{|c|}{ Population in 2015 } & \\
\hline Tanzania & $53,470,420.00$ & \\
\hline Nigeria & $182,201,960.00$ & \\
\hline Zimbabwe & $15,602,750.00$ & \\
\hline Total & $251,275,130$ & \\
\hline In World's Top 50 Entrepreneurial Countries & Population in 2015 & \% of Nigeria's Population \\
\hline South Africa & $55,011,980.00$ & $30.2 \%$ \\
\hline Namibia & $2,458,830.00$ & $1.3 \%$ \\
\hline Botswana & $2,262,490.00$ & $1.2 \%$ \\
\hline Mauritius & $1,262,610.00$ & $0.7 \%$ \\
\hline Total & $60,995,910$ & $33.5 \%$ \\
\hline
\end{tabular}

Table 1: Population per Top Entrepreneurship Countries in Africa

Nigeria's population size in 2015 is nearly three-fourths that of the U.S. white population (73.52 percent) and is four and one-quarter times larger than the U.S. black population (426.2 percent). Nigeria's population is more than half, 56.7 percent, that of the total U.S. population (U.S. Census, 2015). Given the enormous size of Nigeria's informal economy (approximately 60 percent of official GDP) we can surmise that self-employment and entrepreneurship are tremendously prevalent in that country.

Even after considering the number of micro-enterprises in the country, with such a large population size, the number of entrepreneurial firms larger than micro-enterprises may also be substantial. Certainly, empirical investigations in this area will yield interesting results that are likely hidden among mainstream research. Similar investigations in Tanzania and Zimbabwe may also yield surprising and interesting results relative to other regions around the world, including in $O E C D$ countries.

These statistics help shed light on a particular angle not well-discussed in the entrepreneurship literature: While the state of African entrepreneurship can benefit from improvement, it may not be as dismal as it currently seems, especially to outsiders. Researchers can likely learn from insiders who are privy to a different and more complete perspective on African entrepreneurship and thereby help to 
minimize any possible distortions and omissions. Implications of minimizing such distortions are many. Some are discussed later in this paper.

Third, earlier in this paper, we questioned whether any trade-offs between the advantages and disadvantages of operating in either the informal or formal economy differ among entrepreneurs in the U.S. compared to those in Africa. From the findings above on Africa, we now expand our list of trade-offs (See Table 2). We believe Table 2 can serve as a helpful teaching tool to expose entrepreneurs to some of the hidden benefits and costs that accompany their choice of in which economy to operate. Table 2 shows that the choice to operate fully in the formal economy carries 15 advantages, compared to only 6 advantages for choosing to operate fully in the informal economy. Note that the opposite form of each advantage serves as a disadvantage for the counter choice. Solely from a quantitative perspective the choice to operate in the formal economy far surpasses the informal economy choice. Though we do acknowledge that this analysis weights all trade-offs equally. Further studies should assess the relative weights that people making such choices assign to each trade-off.

\begin{tabular}{|l|l|l|l|}
\hline \multicolumn{2}{|c|}{ Advantages of Formal Economy } & \multicolumn{3}{|c|}{ Advantages of Informal Economy } \\
\hline 1 & access to finance and market information & & \\
\hline 2 & access to public infrastructure and services & 1 & legal barriers to entry are sidestepped \\
\hline 3 & enforceable commercial contracts & 2 & set up, licenses, taxation fees avoided \\
\hline 4 & limited liability & 3 & quicker time to launch \\
\hline 5 & clear bankruptcy and default rules & 4 & regulation avoided \\
\hline 6 & $\begin{array}{l}\text { access to government subsidies and incentives, } \\
\text { including procurement bids and export } \\
\text { promotion packages }\end{array}$ & 5 & $\begin{array}{l}\text { non-exposed ...not targeted for non-business- } \\
\text { related expenses (e.g., bribery, extortion). }\end{array}$ \\
\hline 7 & membership in formal business associations & 6 & "unemployed" and "employed" (dual identity) \\
\hline 8 & access to a formal system of social security & & \\
\hline 9 & eligibility for external financing & & \\
\hline 10 & enhanced growth opportunity & & \\
\hline 11 & property rights protection & & \\
\hline 12 & ability to establish a brick-and-mortar presence & & \\
\hline 13 & assets need not remain liquid & & \\
\hline 14 & business can exist on public registries & & \\
\hline 15 & undisputedly employed & & \\
\hline
\end{tabular}

Table 2: Trade-offs of Informal vs. Formal Economy in Africa

\section{Summary and Conclusions}

This study provides two main contributions. First, it argues and introduces evidence to support that, just as the prevalence of black entrepreneurship in the U.S. is likely understated, so too is the prevalence of African entrepreneurship likely understated. Moreover, given Nigeria's huge and growing population size, our study suggests that the number of entrepreneurs in Nigeria may exceed that of many other countries throughout the world. Kenya, Tanzania, Zimbabwe, Ghana, Sierra Leonne, Zambia, and others may be similar.

The second contribution is that this study shows that there are many more advantages to operating in the formal economy than there are to operate in the informal economy. Educators can use our typology in Table 2 to highlight some of these hidden aspects to people who will be confronted with this 
choice. This study also argues that "corruption" as language and usage may serve as a barrier to connecting entrepreneurs in Africa and outsiders who may be seeking people and places to partner with for entrepreneurship. We believe that if people more critically control for regional behaviors, they will find more grounds of commonality than otherwise obvious. Nonetheless, the need to minimize corruption and regulation for new and existing entrepreneurs to increase formal economy entrepreneurship is also supported in this paper.

\section{Policy Implications}

Policy-makers should implement strategies to minimize distortions on entrepreneurship across the African region. For Nigeria, these strategies should include articulating, conveying, and leveraging the large competitive advantage that Nigeria offers in terms of entrepreneurship capital. The way Nigeria is captured in the global entrepreneurship and economic literature versus the way it actually is likely differs. Potential outcomes to minimizing such distortions are many. First, a more favorable environment for FDI may be revealed. This change could encourage Africa's foreign trade partners to participate more strategically in helping to create the types of institutional, legal, and regulatory environments that attract sufficient FDI. Second, a more accurate assessment of entrepreneurial intentions, propensity, and activities may entice investors to look more favorably at social, micro-, and entrepreneurial investment opportunities in the region. Third, given Africa's enormous entrepreneurship human capital, external private foundations may view the entrepreneurial opportunities in partnering with Africans in an increasingly favorable light. Fourth, entrepreneurial universities may look more favorably at recruiting prospective African entrepreneurs to study in their programs abroad.

Because of bounded rationality, informal economy entrepreneurs are likely to perceive only the positive benefits of trading in the informal economy. When more complete information is considered which includes the costs of forgoing the advantages of the formal economy, the rational choice favors choosing to operate in the formal economy. Quantitatively, there are 15 advantages and 6 disadvantages to operating in the formal economy. In contrast, there are only 6 advantages in addition to 15 disadvantages to operating in the informal economy. Recall that the opposite of each advantage is a disadvantage for the opposite choice. Hence, 15:6 yields a much better ratio than 6:15. We therefore believe that education policies promoting awareness of these differences to current and prospective entrepreneurs will yield tremendously positive results.

Governments, academicians, and researchers should investigate the language of corruption, considering the broader political interpretations and implications of its usage. If an outside group such as investors, co-members in a multi-nation organization with regulatory oversight, or larger trade partners, learns that a nation collects license, permits, expedite fees, and other forms of taxation, but that it does so in an informal manner, the potential for interpretational distortions are substantial.

\section{Limitations of Study}

One limitation to this study is that there is no such thing as a one-Africa as a research subject. Africa is extremely rich and diverse in social and political culture, geography, religion, and business contexts. Much more in-depth and country-specific research is needed, versus treating Africa as a singular research subject. An additional limitation to our work is that we do not consider qualitative nor weighted values in our analysis of trade-offs.

\section{Future Research Recommendations}

We have identified several research directions that should help advance knowledge in this very important area of advancing entrepreneurship models in Africa. First, we hope that other researchers will join us in investigating the relative rates of informal economy participation among areas of high black 
population density in different parts throughout the world. Second, future research studies should survey informal economy entrepreneurs to identify weighted averages that these entrepreneurs assign to each trade-off. Research should also identify if any patterns exist among the weights as people change from one economy to the other, or among people who trade simultaneously in both economies. Third, research should investigate the actual number of micro-enterprises versus non-micro-enterprises in countries such as and similar to Nigeria, Tanzania, and Zimbabwe with high informal economy activity. Fourth, research should investigate how informalization moderates or mediates corruption. Fifth, research should investigate if additional hidden entrepreneurial competitive advantages exist in other African countries. Sixth, research should investigate best practices for decreasing regulation in a manner that attracts informal economy entrepreneurs in Africa to the formal economy. Seventh, research should investigate if "corruption" is used as a political language tool for Africa. Our eighth and final recommendation is to investigate ways in which entrepreneurial education programs in outside countries can partner with informal economy entrepreneurs, students, and other entrepreneurs to create entrepreneurial solutions to regional, international, and global problems.

\section{References}

Amine, L.S. and Staub, K.M. (2009). Women entrepreneurs in Sub-Saharan Africa: An institutional theory analysis from a social marketing point of view. Entrepreneurship and Regional Development, 21(2), pp. 183-211.

Atchoarena, D., and Delluc, A. M. (2001). Revisiting technical and vocational education and training in Sub-Saharan Africa. IIEP Paris.

Bates, T. (1996). The financial capital needs of Black-owned businesses. Journal of Developmental Entrepreneurship, 1(1), pp. 1-15.

Bhattacharyya, D.K., and Ghose, S. (1998). Corruption in India and the hidden economy. Economic and Political Weekly, 33(44), pp. 2795-2799.

Bradford, W. D. (2003). The wealth dynamics of entrepreneurship for black and white families in the U.S. Review of Income and Wealth, 49(1), pp. 89-116.

Butler, J. S. (1991). Entrepreneurship and self-help among black Americans: A reconsideration of race and economics. Albany: State University of New York Press.

Chen, M.A. (2012). The informal economy: Definitions, theories and policies. Women in Informal Employment: Globalizing and Organizing (WIEGO), Working Paper, 1-26.

Cross, J.C. (2000). Street vendors, modernity and postmodernity: Conflict and compromise in the global economy. International Journal of Sociology and Social Policy, 20, pp. 29-51.

Crump, M.E.S. (2013). Black entrepreneurship: Formal versus informal economy exploitation. Washington Business Research Journal, 3(1), pp. 85-111.

Crump, M.E.S., Hill, N.J., and Tayor, P.G. (2017). Examining minority population and the impact of informal economy activity on collected revenues in U.S. cities. Washington Business Research Journal, 7(1), pp. 6-41.

DeJaeghere, J. and Baxter, A. (2014). Entrepreneurship education for youth in sub-Saharan Africa: A capability approach as an alternative framework to neoliberalism's individualizing risks. Progress in Development Studies, 14(1), pp. 61-76.

De Soto, H. (1989). The other path: The invisible revolution in the third world. London: Tauris.

Djankov, S., La Porta R., Lopez-de-Silanes F., Shleifer, A. (2002). The Regulation of Entry, The Quarterly Journal of Economics, 117(1), pp. 1-37.

Dreher, A., and Schneider, F. (2010). Corruption and the shadow economy: an empirical analysis. Public Choice, 144(1/2), pp. 215-238.

Edgcomb, E.L., and T. Thetford (2004). The Informal Economy: Making it in Rural America. Aspen Institute: Washington, DC.

Fadahunsi, A., and Rosa, P. (2002). Entrepreneurship and illegality: Insights from the Nigerian cross-border trade. Journal of Business Venturing, 17, pp. 397-429. 
Fairlie, R. W. (1999). The absence of the African-American owned business: An analysis of the dynamics of selfemployment. Journal of Labor Economics, 17(1), pp. 80-108.

Fairlie, R. W., and Meyer, B. D. (1996). Ethnic and racial self-employment differences and possible explanations. The Journal of Human Resources, 31(4), pp. 757-793.

Fairlie, R. W., and Meyer, B. D. (2000). Trends in self-employment among white and black men during the twentieth century. Journal of Human Resources, 35(4), pp. 643-669.

Fairlie, R. W., and Robb, A. M. (2007). Why are black-owned businesses less successful than white-owned businesses? The role of families, inheritances, and business human capital. Journal of Labor Economics, 25(2), pp. $289-323$.

Ford, N (2009). Low valuations hide true worth of Africa's best. African Business, (352), pp. 14-21.

Friedman, E., Johnson, S., Kaufmann, D. and Zoido-Lobaton, P. (2000). Dodging the grabbing hand: The determinants of unofficial activity in 69 countries, Journal of Public Economics, 76(3), pp.459-493.

Godfrey P.C. (2011). Toward a theory of the informal economy, Academy of Management Annals, 5(1), pp. $231-277$.

Goedhuys, M., Mohnen, P., and Taha, T. (2016). Corruption, innovation and firm growth: firm-level evidence from Egypt and Tunisia. Eurasian Business Review, 6(3), pp. 299-322.

Guillermo, V. (2008). What is the size of the pie? Measuring the informal economy in Latin America and the Caribbean. Money Affairs, 21(2), pp. 161-191.

Hofstede, G. (1983). National cultures in four dimensions - A research-based theory of cultural differences among nations. International Studies of Management and Organization, 13(1-2), pp. 46-74.

Hout, M., and Rosen, H. S. (2000). Self-employment, family background, and race. Journal of Human Resources, 35(4), pp. 670-692.

International Labour Office, 2012. International Standard Classification of Occupations, ISCO-08 (Geneva). ------- 2012. Women in Informal Employment: Globalizing and Organizing

(WIEGO). 2012. Women and men in the informal economy 2012 - A statistical picture (Geneva).

Johnson, S., Kaufmann, D., Zoido-Lobaton, P. (1998). Regulatory discretion and the unofficial economy, The American Economic Review, 88(2), pp.387-392.

Kaufmann, D. (1997). Corruption: the facts. Foreign Policy, 107, pp.114-131. Kent, D. W., and Mushi, P. S. (1995). The Education and Training of Artisans for the Informal Sector in Tanzania. Education Research. Serial No. 18.

Khavul, S., Bruton, G. D., and Wood, (2009). Informal family business in Africa. Entrepreneurship: Theory and Practice, 33(6), pp. 1219-1238.

Kiggundu, Moses N. (2002). Entrepreneurs and entrepreneurship in Africa: What is known and what needs to be done. Journal of Developmental Entrepreneurship, 7(3), pp. 239-258.

Klapper, L., and Love, I. (2010). The Impact of Business Environment Reforms on New Firm Registration. World Bank Policy Research Working Paper No. 5493. Available at SSRN: https://ssrn.com/abstract=1721331

Köllinger, P., and Minniti, M. (2006). Not for lack of trying: American entrepreneurship in black and white. Small Business Economics, 27(1), pp. 59-79.

Krizinger, E. and von Solms, SH (2012). A framework for cyber security in Africa. Journal of Information Assurance and Cybersecurity, (2012), pp. 1-10.

Kshetri, K. (2011). Institution and economic foundations of entrepreneurship in Africa: An overview. Journal of Developmental Entrepreneurship, 16(1), pp. 9-35.

Kus, B. (2010). Regulatory governance and the informal economy: Cross-national comparisons, Socio-Economic Review, 8, pp. 487-510.

Libombo, D.B. and Dinin, A. (2015). Entrepreneurship education in the context of developing countries: Study of the status and the main barriers in Mozambican higher education institutions. Journal of Developmental Entrepreneurship, 20(3), pp. 1-26.

Macias, B. and Cazzavillan, G. (2010). Modelling the informal economy in Mexico. A structural equation approach. The Journal of Developing Areas, 44(1), pp. 345-365.

Maloney, W. F. (2004). Informality revisited. World Development, 32(7), pp. 1159-1178. Mbaku, JM (2007). Institutions and Poverty Alleviation in Africa. African and Asian Studies, 6(1/2), pp. 107-134.

Mitra, D (1999). Endogenous Lobby Formation and Endogenous Protection: A Long-Run Model of Trade Policy Determination. American Economic Review, 89(5), pp. 1116-1134. 
Mukherjee, D., 2016. Informal economy in emerging economies: Not a substitute but a complement! International Journal of Business and Economic Development, 4(3) pp. 16-27.

Munemo, Jonthan (2012). Entrepreneurship in developing countries: Is Africa different? Journal of Developmental Entrepreneurship, 17(1), pp. 1-12.

Murthy, V. N., Nath, R., and Soleimani, M. (2015). Long term factors of internet diffusion in Sub-Saharan Africa: A Panel Co-Integration Analysis. Journal of International Technology and Information Management, 24(4), pp. 5.

Musarurwa, A., and Jazri, H. (2014). A proposed framework to measure growth of critical information infrastructure protection in Africa. International Conference on Emerging Trends and Computer Communications, May. Namibia. pp. 85-90.

Mvunganyi, J (2010). African Youth Bear Brunt of Global Economic Crisis, 25 January, available at: http:/ / www1.voanews.com/english/news/africa/African-Youth-Bear-Brunt-of-Global-Economic-Crisis82601422.html

Okpara, J. O., and Wynn, P. (2007). Determinants of small business growth constraints in a Sub-Saharan African economy. SAM advanced management journal, 72(2), pp. 24.

Oladipo, Tomi (2015). Cyber-crime is Africa's 'next big threat', experts warn. BBC.

Olson, M (1996). Big bills left on the sidewalk: Why some Nations are rich, and others are poor. Journal of Economic Perspectives, 10, pp. 3-24.

Omer, N., Van Burg, E., Peters, R. M., and Visser, K. (2015). Internationalization as a “work-around” strategy: How going abroad can help SMEs overcome local constraints. Journal of Developmental Entrepreneurship, 20(2), pp. 122.

Prahalad, CK (2005). Aid is not the answer. Wall Street Journal (Eastern edition), A.8.

Rheault, M and B Tortora (2008). Nigeria: Drivers and challenges of entrepreneurship.

www.gallup.com/poll/106345/nigeria-drivers-challenges-entrepreneurship.aspx.

Rin, M., Sembenelli, A., and Giacomo, M. (2010). Corporate taxation and the size of new firms: evidence from Europe. Journal of the European Economic Association, 8(2-3), pp. 606-616.

Robinson, P.J.A., Haugh, H.M., and Obeng, B.A. (2009). Entrepreneurship and innovation in Ghana: Enterprising Africa. Small Business Economics, 32, pp. 331-350.

Schneider, F. (2002). Size and measurement of the informal economy in 110 countries around the world. Paper presented at Workshop of Australian National Tax Centre, Canberra, Australia.

(2005a). Shadow economies around the world: what do we really know? European Journal of Political Economy, 21(3), pp. 598-642.

(2005b). The size of shadow economies in 145 countries from 1999 to

2003. The Brown Journal of World Affairs. 11(2), pp. 113-129.

Schuck, P. H., and Litan, R. E. (1987). Regulatory reform in Peru regulation. AEI Journal on Government and Society, 11(1), pp. 36-43.

Shleifer, A. (1997). The government in transition. European Economic Review, 41(3), pp.385-410.

Shleifer, A., Vishny, R. (1993). Corruption. Quarterly Journal of Economics, 108, pp. 599-618.

---- (1994). Politicians and firms. Quarterly Journal of Economics, 109, pp.995-1025.

---- (1998). The grabbing hands. Harvard University Press.

Sievers, SE (2001). Competitiveness and foreign direct investment in Africa. In Policies to Promote Competitiveness in Manufacturing in Sub-Saharan Africa, SM Nsouli (eds.). Paris: Organization for Economic Cooperation and Development.

Singh, R. P., Crump, M. E. S., and Zu, X. (2009). Family matters: Examining how self-

employed blacks and whites differ in having self-employed parents. In Bradshaw, M..V. and Carrington, P. T. (eds.) Entrepreneurship and its Economic Significance, Behavior and Effects (pp. 1-20). New York, NY: Nova Science Publishers.

Snyder, K.A. (2004). Routes to the informal economy in New York's East village: crises, economics and identity. Sociological Perspectives, 47, pp. 215-240.

Svensson, J. (2005). Eight questions about corruption. Journal of Economic Perspectives, 19(3), pp. 19-42. 
The Economist (2006). Special Report: The flicker of a brighter future - Business in Africa, Business in Africa, 380(8494), pp. 80.

Walstad, W. B., and Kourilsky, M. L. (1998). Entrepreneurial attitudes and knowledge of black youth. Entrepreneurship Theory and Practice, 23(2), pp. 5-18.

Webb, J.W., L. Tihanyi, R.D. Ireland, and D.G. Sirmon (2009). You say illegal, I say legitimate: Entrepreneurship in the informal economy. Academy of Management Review, 34, pp. 492 - 510.

Williams, C.C. (2008). Beyond necessity-driven versus opportunity-driven entrepreneurship: a study of informal entrepreneurs in England, Russia and Ukraine. International Journal of Entrepreneurship and Innovation, 9, pp. 157-166.

Williams, C.C. (2010). Spatial variations in the hidden enterprise culture. Entrepreneurship and Regional Development, 22, pp. 403-423.

Williams, C.C, and S. Nadin (2010). The commonality and character of off-the-books entrepreneurship: a comparison of deprived and affluent urban neighbourhoods. Journal of Developmental Entrepreneurship, 15, pp. 1-14.

Williams, C.C., and J. Round (2007). Entrepreneurship and the informal economy: a study of Ukraine's hidden enterprise culture. Journal of Developmental Entrepreneurship, 12, pp. 119-136.

Williams, C.C., and J. Round (2008). Retheorizing the nature of informal employment: some lessons from Ukraine. International Sociology, 23, pp. $367-388$.

Williams, C.C., and J. Round (2010). Spatial variations in the character of off-the-books entrepreneurship: lessons from a study of contrasting districts in Moscow. International Journal of Entrepreneurship and Small Business, 10, pp. 287-301.

Williams, C.C., and Shahid, M.S. (2016). Informal entrepreneurship and institutional theory: Explaining the varying degrees of (in)formalization of entrepreneurs in Pakistan. Entrepreneurship and Regional Development, 28(1-2), pp. $1-25$.

Worldbank.org. 2015. Available Online at: http://data.worldbank.org/indicator/SP.POP.TOTL?cid=GPD_1.

[Accessed 14 May 2017]. 